\title{
A Tiny New Brazilian Species of Diandrolyra (Poaceae, Bambusoideae, Olyreae), with Notes on the Systematics of the Genus
}

Author(s): Reyjane Patricia de Oliveira and Lynn G. Clark

Source: Novon: A Journal for Botanical Nomenclature, 19(2):209-214. 2009.

Published By: Missouri Botanical Garden

DOI: http://dx.doi.org/10.3417/2007067

URL: http://www.bioone.org/doi/full/10.3417/2007067

BioOne (www.bioone.org) is a nonprofit, online aggregation of core research in the biological, ecological, and environmental sciences. BioOne provides a sustainable online platform for over 170 journals and books published by nonprofit societies, associations, museums, institutions, and presses.

Your use of this PDF, the BioOne Web site, and all posted and associated content indicates your acceptance of BioOne's Terms of Use, available at www.bioone.org/ page/terms_of_use.

Usage of BioOne content is strictly limited to personal, educational, and noncommercial use. Commercial inquiries or rights and permissions requests should be directed to the individual publisher as copyright holder. 


\title{
A Tiny New Brazilian Species of Diandrolyra (Poaceae, Bambusoideae, Olyreae), with Notes on the Systematics of the Genus
}

\author{
Reyjane Patricia de Oliveira
}

Programa de Pós-graduação em Botânica, Departamento de Ciências Biológicas, Universidade Estadual de Feira de Santana, Rodovia BR 116N, Km 3, Feira de Santana, Bahia, 44031-460, Brazil. Current address: Universidade Federal da Bahia, Departamento de Botânica, Av. Ademar de Barros s/n, Ondina 40171-970, Salvador, Bahia, Brazil. rpolliveira@yahoo.com

\section{Lynn G. Clark}

Department of Ecology, Evolution and Organismal Biology, Iowa State University, Ames, Iowa 50011-1020, U.S.A. lgclark@iastate.edu

Abstract. A new species of Diandrolyra Stapf (Poaceae, Bambusoideae, Olyreae), D. pygmaea Soderstrom \& Zuloaga ex R. P. Oliveira \& L. G. Clark, from Bahia, Brazil, is described and illustrated. This species is known only from southern Bahia, growing in the Atlantic Forest region. It is compared and contrasted with its congeners, D. bicolor Stapf and D. tatianae Soderstrom \& Zuloaga, and the Bahian distribution of the three species is mapped. Distinguishing features of D. pygmaea include its small stature and two (or three) pairs of spikelets per racemose inflorescence.

Resumo. Uma nova espécie de Diandrolyra Stapf (Poaceae, Bambusoideae, Olyreae), D. pygmaea Soderstrom \& Zuloaga ex R. P. Oliveira \& L. G. Clark, para a Bahia, Brazil, está sendo descrita e ilustrada. Esta espécie é conhecida apenas para o sudeste da Bahia, crescendo em áreas de Mata Atlântica higrófila. Está sendo comparada com as outras espécies congenéricas, D. bicolor Stapf e $D$. tatianae Soderstrom \& Zuloaga, e a distribuição das três espécies na Bahia é mapeada. Características distintivas de D. pygmaea incluem sua pequena estatura e dois (ou três) pares de espiguetas por inflorescência racemosa.

Key words: Atlantic rainforest, Bahia, Bambusoideae, Brazil, Diandrolyra, IUCN Red List, Olyreae, Poaceae.

Diandrolyra is a rare grass genus, described by Stapf (1906). The generic name refers to the reduced stamen number, from three (as occurs in other genera of Olyreae, e.g., Olyra L., Cryptochloa Swallen, and Raddia Bertoloni) to two. This genus is also distinguished from other herbaceous bamboos by flowering culms typically bearing only one fully developed and specialized leaf blade, which is appressed to and overtops the single contracted inflorescence (Judziewicz et al., 1999). This inflorescence is inconspicuous and completely hidden under the abaxial surface of the leaf blade when the plant is viewed from above, which makes Diandrolyra species appear to always be sterile (Fig. 1D).

Based on the presence of often raceme-like inflorescences borne on specialized culms (Fig. 1B, C, E), Clayton and Renvoize (1986) considered Diandrolyra to belong to a group including Piresia Swallen, which is disjunct between the Amazon Basin and the Atlantic Forest region, as well as Mniochloa Chase and Ekmanochloa Hitchcock, endemics to Cuba, and Buergersiochloa Pilger, endemic to New Guinea. Among these genera, Piresia was consistently indicated as most related to Diandrolyra (Soderstrom \& Calderón, 1974; Clayton \& Renvoize, 1986), principally due to the presence of polygamous spikelets with incomplete sexual separation (female spikelets with staminodes and male spikelets with a sterile ovary bearing three stigmas).

Preliminary molecular studies in the tribe Olyreae (Oliveira, 2006), however, do not support a relationship between Diandrolyra and Piresia. ITS sequence data provide weak support for a sister relationship between Diandrolyra and Cryptochloa capillata (Trinius) Soderstrom, which has conspicuously dimorphic male and female spikelets. However, plastid trnD-trnT sequence data used in the same work (Oliveira, 2006) strongly support Diandrolyra as sister to a clade containing Parodiolyra Soderstrom \& Zuloaga and Raddiella Swallen.

Diandrolyra is endemic to the Atlantic Forest of Brazil, from Bahia to São Paulo (Soderstrom et al., 1988; Clark, 1990), occurring in lowlands below $400 \mathrm{~m}$, often in very shaded areas, sometimes near running water. Only two species are presently formally 

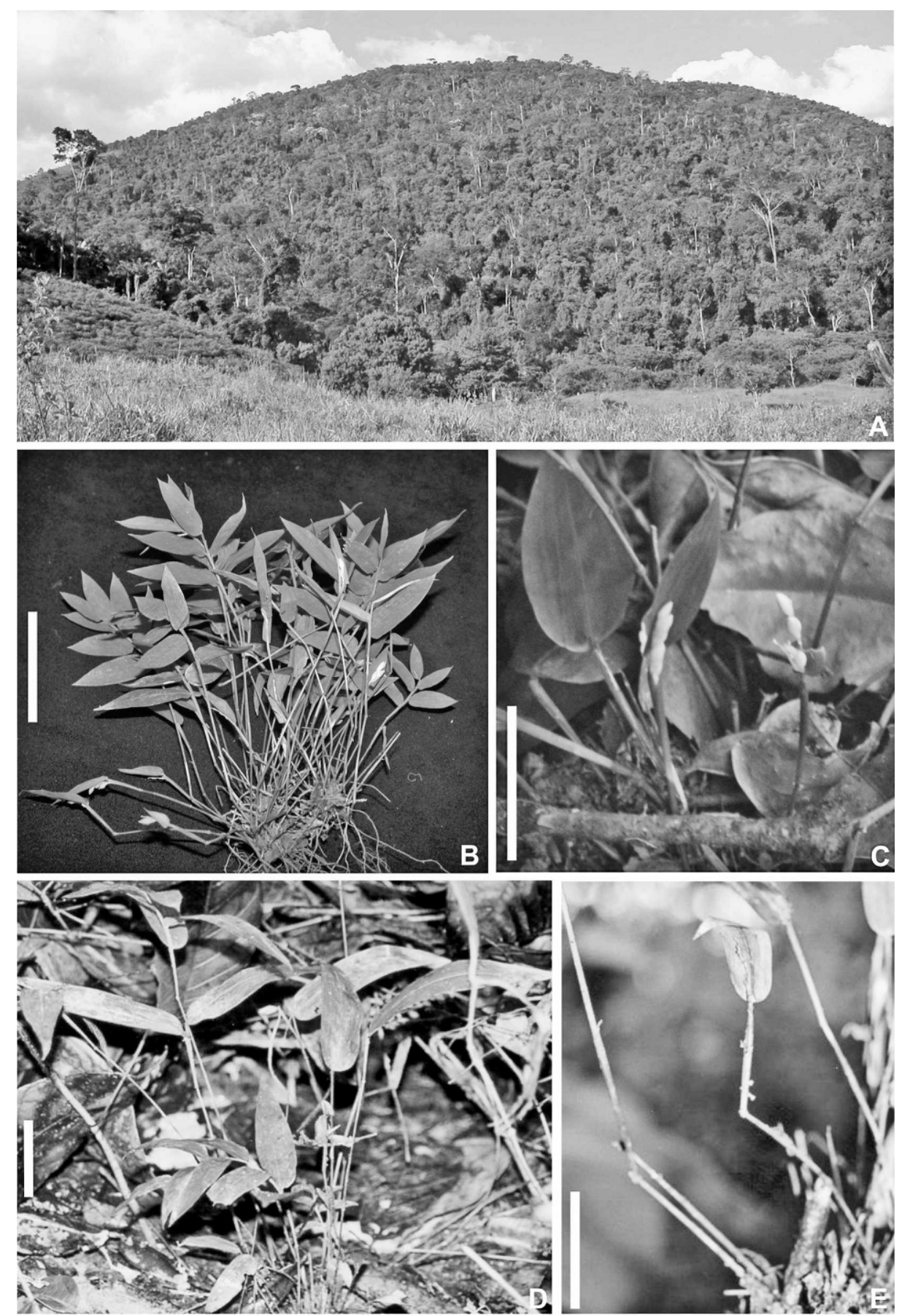

Figure 1. - -A. Atlantic mesophyllous forest at Itanhém, Bahia, Brazil. —B. Diandrolyra pygmaea. — C. Diandrolyra bicolor. -D, E. Diandrolyra tatianae. Photos: A, B by André M. Amorim; C-E by R. P. Oliveira. Scale bars $=5 \mathrm{~cm}$.

described, D. bicolor Stapf (Fig. 1C), occurring in Bahia, Espírito Santo, and Rio de Janeiro states, and D. tatianae Soderstrom \& Zuloaga (Fig. 1D, E), which has a wider distribution, known from São Paulo, Rio de Janeiro, Espírito Santo, Minas Gerais, and Bahia states (Oliveira, 2001). Estimates have given possibly as many as five (Soderstrom \& Zuloaga, 1985) or six species (Clayton \& Renvoize, 1986) for this taxonomically difficult genus, as each of the two described species are not well defined morphologically and more 
than one taxon may be included in their current circumscriptions (Oliveira et al., 2006).

Thomas Soderstrom and colleagues first became interested in Olyreae, including Diandrolyra, in the 1960s (Calderón \& Soderstrom, 1967). They initiated a systematic revision of this genus in the 1970 s as part of their studies on Neotropical Bambusoideae. Several new species among olyroid genera were proposed by these authors, but they were not published before Soderstrom's untimely death (1936-1987). Soderstrom (1984) showed a photograph of and informally mentioned a third, tiny and small-leaved new species of Diandrolyra from Bahia, which was also commented on in Soderstrom and Zuloaga (1985).

During a floristic survey of Olyreae from the state of Bahia (Oliveira, 2001), several herbarium specimens were found annotated as Diandrolyra pygmaea by Soderstrom and Zuloaga, and a recent collection was made from the only population of this species still known to exist. We herein validate this taxon and discuss its conservation status. Information on the occurrence of other Diandrolyra species in Bahia is based on Oliveira (2001).

\section{Key to the Species of Diandrolyra}

la. Vegetative culms $8.5-19 \mathrm{~cm}$ tall; leaf blades of vegetative culms $1.8-3(-4) \times 0.2-0.8 \mathrm{~cm}$; leaf blades of flowering culms $1.7-2.9 \times 0.3-0.5 \mathrm{~cm}$; racemes with 2(3) pairs of spikelets.... D. pygmaea

lb. Vegetative culms $15-50 \mathrm{~cm}$ tall; leaf blades of vegetative culms $6-16 \times 1-4.5 \mathrm{~cm}$; leaf blades of flowering culms $3-6.2 \times 0.9-1.6 \mathrm{~cm}$; racemes with 4 to 6 pairs of spikelets . . . . . . . . . 2

2a. Racemes with 5 or 6 pairs of spikelets; leaf blades often pale green, glabrous; leaf blades of vegetative culms $8.5-16 \times(2-) 2.7-4.5 \mathrm{~cm}$; lemma of male spikelet scabrous or glabrous . . . . . . D. tatianae

2b. Racemes with 4 pairs of spikelets; leaf blades strongly bicolored, pilose on the abaxial surface; leaf blades of vegetative culms $6-8(-11) \times 1-2$ $(-2.5) \mathrm{cm}$; lemma of male spikelet sparsely pilose

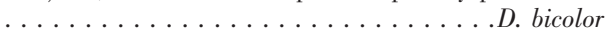

Diandrolyra pygmaea Soderstrom \& Zuloaga ex R. P. Oliveira \& L. G. Clark, sp. nov. TYPE: Brazil. Bahia: Itabuna, on rd. Ilheus-Itabuna, area da CEPLAC [Centro de Pesquisas do Cacau], 1 May 1976, C. E. Calderón, T. S. Santos \& L. B. Oliveira 2407 (holotype, CEPEC; isotypes, INPA, US). Figures 1B, 2.

Haec species a congeneris planta minore (8.5-19 cm alta), laminis foliaribus minoribus (eis culmorum vegetativorum $1.8-3[-4] \mathrm{cm}$ longis) et racemo ex 2(3) paribus tantum spicularum constante differt.

Plants caespitose, without rhizomes; vegetative culms 8.5-19 cm, 0.6-1 mm diam., shortly pilose, with 4 to 8 leaves, green on both surfaces, nodes scabrous or puberulent; flowering culms 4-7 cm, 0.5-
$1 \mathrm{~mm}$ diam., scabrous, bearing 1 or rarely 2 leaves, green on both surfaces, nodes scabrous or puberulent. Leaf sheaths glabrous or sometimes fully pilose; leaf blades of vegetative culms $1.8-3(-4) \times 0.2-0.8 \mathrm{~cm}$, those of the flowering culms $1.7-2.9 \times 0.3-0.5 \mathrm{~cm}$, lanceolate, glabrous on both surfaces or pilose only on the abaxial surface, base symmetrical or slightly asymmetrical, rounded, margins scabrous, apex acute; pseudopetiole $0.5-1 \mathrm{~mm}$, hirsute on both surfaces; ligule $0.2-0.3 \mathrm{~mm}$; sheath auricles absent. Inflorescence a raceme $0.7-1 \mathrm{~cm}$, with $2(3)$ pairs of female and bisexual but functionally male spikelets, with a male at the apex, these borne on one side of the axis; axis glabrous. Female spikelets $4.8-5 \times 1.4-1.6 \mathrm{~mm}$, ovoid or ellipsoid, acute, the base of the glumes fused, thickened, and presenting a tuft of hairs; pedicel shortly pilose; glumes $4.5-5 \mathrm{~mm}$, membranous, subequal, acute, sparsely pilose, especially at the base and on the nerves, 5- to 7-nerved; anthecium 4-4.3 $\times$ 1.2-1.5 mm, ovoid-ellipsoid, stramineous; lodicules 3 , conspicuous; staminodes absent; caryopsis ellipsoid, ca. $3 \times 1 \mathrm{~mm}$, hilum linear, as long as the caryopsis. Male spikelets similar but ca. $3 \times 0.5 \mathrm{~mm}$, lanceolate; glumes very short, not fused, and without a tuft of hairs, sparsely pilose, 5-nerved; lemma acuminate, sparsely pilose, 3-nerved; lodicules 3, conspicuous; stamens 2 , anthers $0.6-0.8 \mathrm{~mm}$; pistillodes present.

Distribution and habitat. Plants of Diandrolyra pygmaea are very delicate, and the species is distinguished from its congeners by its small height and reduced number of leaf blades, as well as the small number of spikelet pairs in each raceme. This species is endemic to southern Bahia, where the other two Diandrolyra species also occur (Fig. 3). This new species was found in humid forests along with ferns and other small herbaceous plants, but it is also found in transitional to mesophyllous forest at the Itanhém site (Fig. 1A). It prefers shady, humid places and persists under trees of Theobroma cacao L. plantations.

IUCN Red List category. Diandrolyra pygmaea is known from only two localities in southern Bahia, and only the population from Itanhém has been found during recent field trips. The populations collected by Calderón and Soderstrom were not relocated and are possibly now destroyed, because the native forest has been converted to ample areas of grasslands. For these reasons, we suggest that $D$. pygmaea should be considered Critically Endangered (CR) according to IUCN Red List criteria (IUCN, 2001), as has been recently proposed for several other herbaceous bamboos occurring in this same 


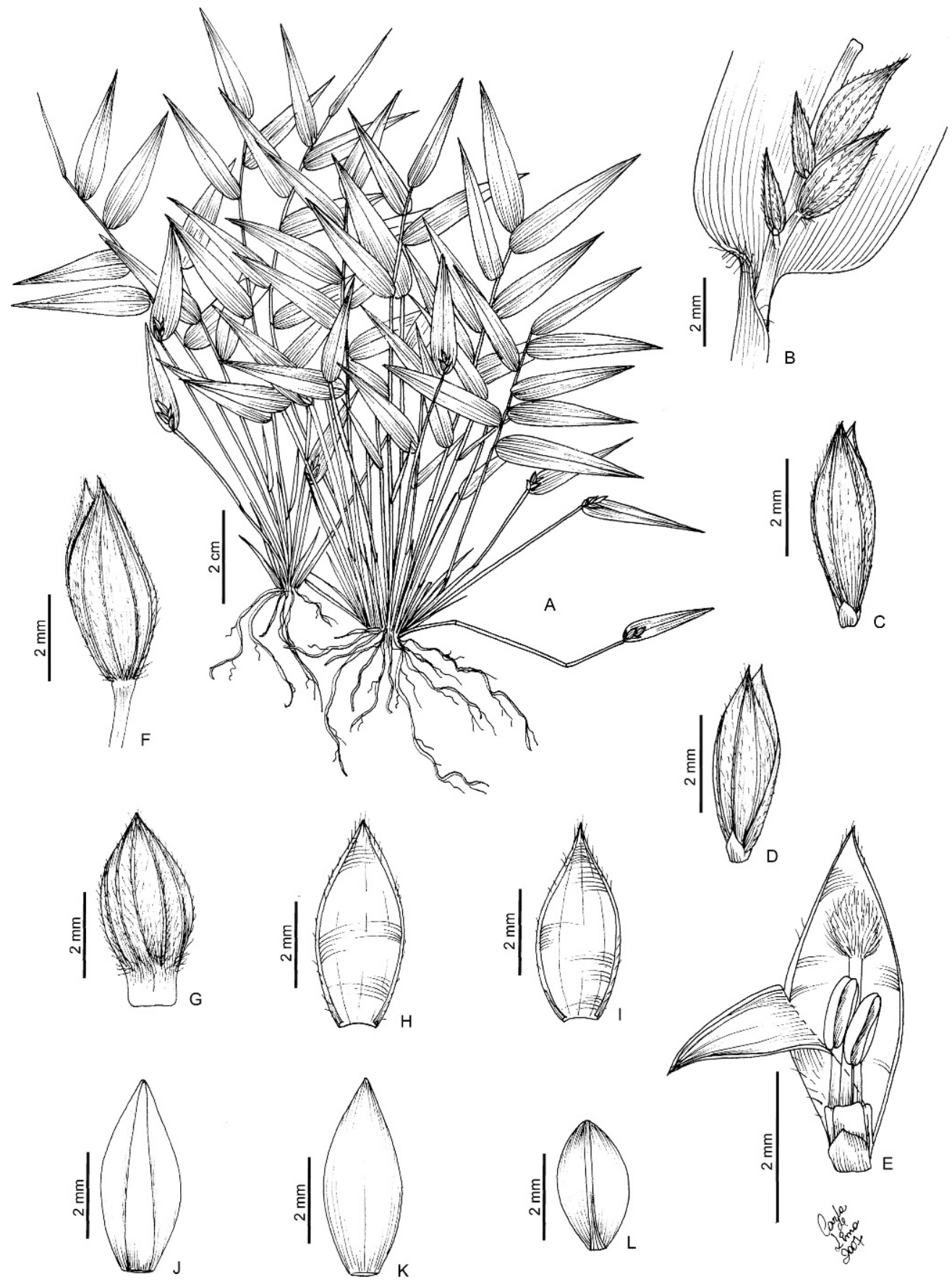

Figure 2. Diandrolyra pygmaea Soderstrom \& Zuloaga ex R. P. Oliveira \& L. G. Clark. - A. Habit. —B. Detail of the inflorescence near the base of the leaf blade, showing two pairs of spikelets (on left, the bisexual and functionally male, and right, the female ones). - C, D. Male spikelet (bisexual, but functionally male) closed, dorsal view. —E. Male spikelet opened, showing two stamens, three lodicules, and reduced female structures of stigma and style (without ovary developed). - F, G. Female spikelets closed, dorsal view. - H, I. Glumes of the female spikelets, ventral view. -J. Female anthecium, ventral view. -K. Female anthecium, dorsal view. - L. Caryopsis with linear hilum. Drawn from the holotype C. E. Calderón et al. 2407 (CEPEC), by Carla de Lima. 


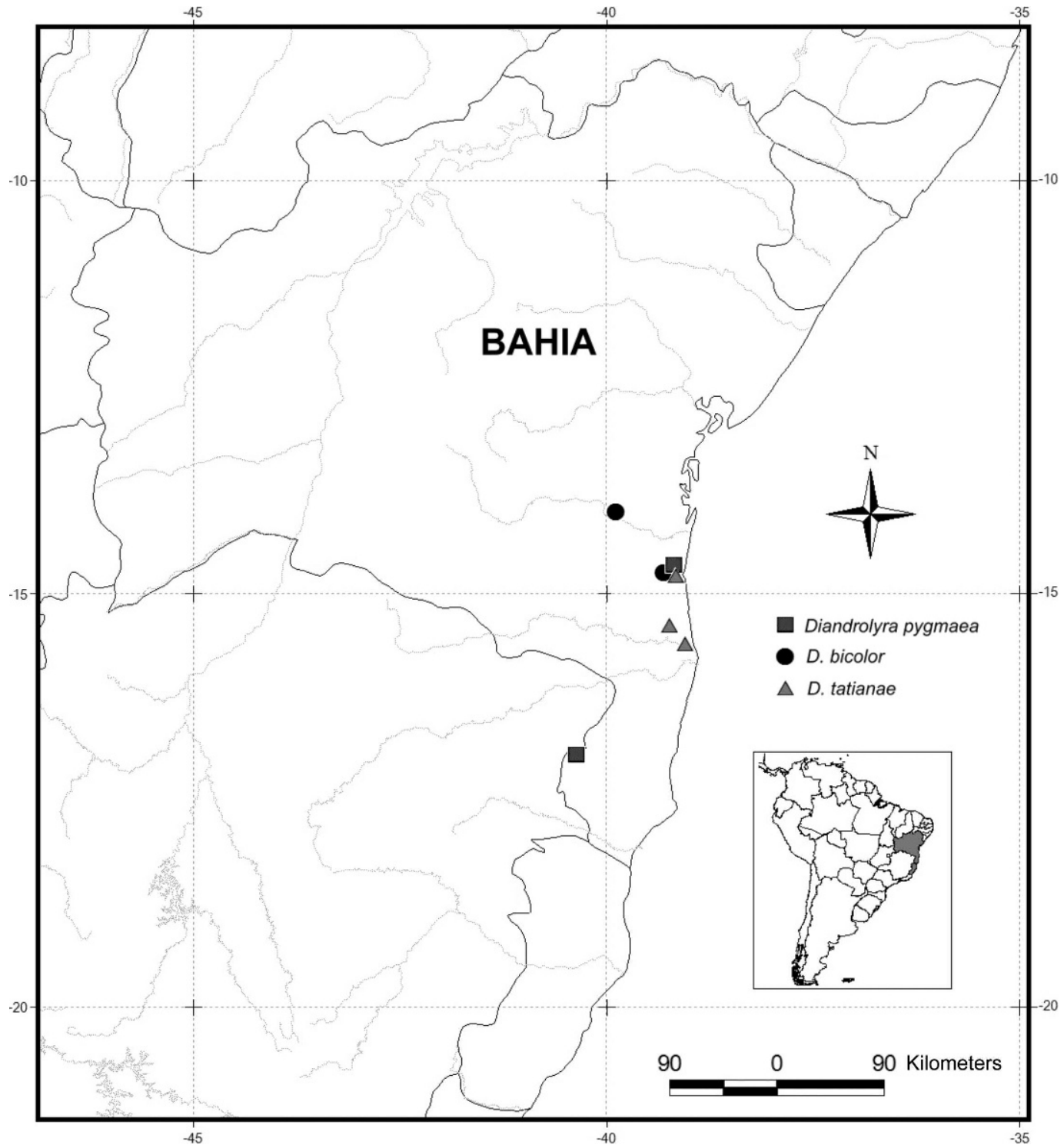

Figure 3. Distribution map of Diandrolyra pygmaea and other congeneric species occurring in Bahia, Brazil.

region (Oliveira et al., 2004; Oliveira \& LonghiWagner, 2005).

Paratypes. BRAZIL. Bahia: Ilhéus, Area do CEPLAC, Km 22 Rod. Ilhéus-Itabuna (BR 415), 50 m, 29 Oct. 1983, T. S. Santos \& T. R. Soderstrom 3917 (ISC, US); Itabuna, Ferradas, Faz. Aberta Grande, $14 \mathrm{~km} \mathrm{SW}$ of Itabuna, ca. $14^{\circ} 51^{\prime} \mathrm{S}, 39^{\circ} 20^{\prime} \mathrm{W}, 100$ m, 8 Mar. 1972, C. E. Calderón \& R. S. Pinheiro 2159 (CEPEC, K, NY, US), 10 Mar. 1972, C. E. Calderón \& R. S. Pinheiro 2163 (CEPEC, K, MO, US); Itanhém, estrada Itanhém a Batinga, ca. $16 \mathrm{~km}$ ramal à direita, dando acesso à Faz. Pedra Grande, de prop. Etevaldo Rezende da Silva, $17^{\circ} 8^{\prime} 17^{\prime \prime} \mathrm{S}, 40^{\circ} 25^{\prime} 34^{\prime \prime} \mathrm{W}, 29$ Dec. $2004, A$. M. Amorim, J. G. Jardim, J. L. Paixão V. Faladelfo \& S. C. Sant'Anna 4590 (CEPEC, HUEFS); $17^{\circ} 07^{\prime} 57.8^{\prime \prime} \mathrm{S}$,
40 25'17.8"W, 260-300 m, 18 Mar. 2001, W. W. Thomas, J. Jardim, F. Juchum \& A. Carvalho 12340 (CEPEC, HUEFS, NY).

Acknowledgments. We are grateful to the Universidade Estadual de Feira de Santana for the financial support for the field trips; André Amorim, curator of the Herbarium CEPEC, for specimen loans and some photographs; Hilda Longhi-Wagner and Jomar Jardim for help in fieldwork; W. Wayt Thomas for collected materials; and Cassio van den Berg for the Latin diagnosis. The first author also thanks Conselho Nacional de Desenvolvimento Científico e Tecnológico 
(CNPq) and Fundação de Amparo à Pesquisa do Estado da Bahia (FAPESB) for the fellowships received. We thank Fernando Zuloaga and Steve Renvoize for helpful comments on the manuscript.

\section{Literature Cited}

Calderón, C. E. \& T. R. Soderstrom. 1967. Las Gramineas Tropicales Afines a "Olyra" L. Atas do Simpósio sôbre a Biota Amazônica, Vol. 4 (Botânica), 67-76.

Clark, L. G. 1990. Diversity and biogeography of neotropical bamboos (Poaceae: Bambusoideae). Acta Bot. Brasil. 4: 125-132.

Clayton, W. D. \& S. A. Renvoize. 1986. Genera Graminum: Grasses of the World. Royal Botanic Gardens, Kew, Richmond, Surrey.

IUCN. 2001. IUCN Red List Categories and Criteria, Version 3.1. Prepared by the IUCN Species Survival Commission. IUCN, Gland, Switzerland, and Cambridge, United Kingdom.

Judziewicz, E. J., L. G. Clark, X. Londoño \& M. J. Stern. 1999. American Bamboos. Smithsonian Institution Press, Washington, D.C.

Oliveira, R. P. 2001. A Tribo Olyreae (Poaceae: Bambusoideae) no Estado da Bahia, Brasil. Masters Thesis, Universidade Estadual de Feira de Santana, Feira de Santana, Bahia.

—. 2006. Estudos Taxonômicos, Filogenéticos e Biosistemáticos em Raddia Bertoloni (Poaceae, Bambusoideae, Olyreae). Ph.D. Dissertation, Universidade Estadual de Feira de Santana, Feira de Santana, Bahia.
\& H. M. Longhi-Wagner. 2005. Olyra bahiensis (Poaceae-Olyreae): Uma nova espécie para a mata atlântica do estado da Bahia, Brasil. Revista Brasil. Bot. 28(4): 835-839.

$\longrightarrow,-1$ V. C. Hollowell. 2004. A new species of Pariana (Poaceae: Bambusoideae: Olyreae) endemic to the Atlantic moist forest in the State of Bahia, Brazil. Novon 14: 206-209.

— \& J. G. Jardim. 2006. Diversidade e conservação dos bambus herbáceos (Poaceae: Bambusoideae: Olyrae) da Mata Atlântica, Brasil. Pp. 62-66 in J. G. Almeida \& A. A. Teixeira (orgs.), Anais do Simpósio Nacional sobre Bambus. Universidade Federal de Brasília, Brasília, Distrito Federal.

Soderstrom, T. R. 1984. In quest of the pygmy bamboos. Fairchild Trop. Gard. Bull. 39: 6-15.

\& C. E. Calderón. 1974. Primitive forest grasses and evolution of the Bambusoideae. Biotropica 6(3): 141153.

\& F. O. Zuloaga. 1985. Diandrolyra tatianae (Poaceae: Olyreae), a new herbaceous bamboo from Brazil. Brittonia 37: 1-5.

— E. J. L. Judziewicz \& L. G. Clark. 1988. Distribution patterns in Neotropical bamboos. Pp. 120-156 in P. E. Vanzolini \& W. R. Heyer (editors), Proceedings of the Neotropical Biotic Distribution Pattern Workshop, Rio de Janeiro, 1987. Academia Brasileira de Ciências, Rio de Janeiro.

Stapf, O. 1906. XXXIV, Decades Kewenses. In Plantarum Novarum in Herbario Horti Regii Conservatarum. Decas XLII. Bull. Misc. Inform. Kew 6: 200-205. [Diandrolyra, pp. 204-205.] 